\title{
The WWII German Heavy Artillery Battery AV 67 of Cleus Foz (Finistère-FR)
}

\author{
Giancarlo T. Tomezzoli \\ Etno-Archaeological Observatory, Munich, Germany \\ Email: gt21949@gmx.de
}

How to cite this paper: Tomezzoli, G. T. (2017). The WWII German Heavy Artillery Battery AV 67 of CleusFoz (Finistère-FR). Archaeological Discovery, 5, 61-78. https://doi.org/10.4236/ad.2017.52004

Received: January 3, 2017

Accepted: April 26, 2017

Published: April 29, 2017

Copyright $\odot 2017$ by author and Scientific Research Publishing Inc. This work is licensed under the Creative Commons Attribution International License (CC BY 4.0).

http://creativecommons.org/licenses/by/4.0/

\begin{abstract}
The reading of literature concerning the Atlantic Wall and of the previously published articles may have conveyed the concept that the German military structures of the Atlantic Wall were formed by Regelbauten (rule-built constructions) ( $R \mathrm{~s}$ ). This concept is not totally wrong, but leads to neglect the important role played by the verstärktenfeldmäßigen Bauwerke (strengthened field constructions) ( $V f)$ normally included in said structures. The present article, concerning the visit of the site of the WW II German heavy artillery battery of Cleus Foz (Finistère-FR) and the discussion of its organization, show that the $V f s$ in this battery represented the majority of its bunkers, and in this way indicate how said concept should be corrected.
\end{abstract}

\section{Keywords}

World War II, Third Reich, Atlantic Wall, Cleus Foz, AberWrach, $V f$, Finistère, Brittany

\section{Introduction}

The reading of literature concerning the Atlantic Wall (Dupont, 1994) (Chazette, 1995) (Duquesne, 1976) and of previous published articles (Tomezzoli \& Marzin, 2015) (Tomezzoli \& Pottier, 2016a) (Tomezzoli \& Pottier, 2016b) (Tomezzoli, 2017), describing the surviving components of the German military structures of the Atlantic Wall, may have conveyed the concept that they were formed by Regelbauten (rule-built constructions) ( $R s$ ). This concept is not totally wrong, but leads to neglect the role played by the verstärktenfeldmäßigen Bauwerke (strengthened field constructions) (Vf) often included in said structures. The $V f \mathrm{~s}$ were bunkers of various designs, conceived for resisting to bombs up to $50 \mathrm{~kg}$ on the coverage and $105 \mathrm{~mm}$ direct impacts on the walls. The Vfs of the WW II 
heavy artillery battery of Cleus Foz (Finistère-FR) integrated the $R$ s offering easy and rapid solutions to the necessities of storing materials, lodging personnel and providing combat positions.

\section{The Battery Site of Cleus Foz}

The German heavy artillery battery of Cleus Foz $\left(48^{\circ} 35^{\prime} 01.20^{\prime \prime} \mathrm{N}, 4^{\circ} 33^{\prime} 01.42^{\prime \prime} \mathrm{W}\right)$ coded $A V 67$ (Patrimoine Region Bretagne, 2002) comprised one bunker R669, three open heavy gun emplacements for $150 \mathrm{~mm}$ s.F.H.25 captured Czech $M-25$ Skoda rough howitzers, two $M 134$, two FlakVf emplacements and at least other $12 \mathrm{Vfs}$. The battery was probably evacuated at the retreat of the German troops towards the Festung (fortress) Brest on August 1944, and the bunkers, fortunately, were not dynamited. The visit took place on 06/09/2016 and, regrettably, nobody was on the base site to who raise questions.

The $R 669\left(48^{\circ} 35^{\prime} 0.16^{\prime \prime} \mathrm{N}, 4^{\circ} 33^{\prime} 3.75^{\prime \prime} \mathrm{W}\right)$ (1) (Figure 1 \& Figure 2), was similar to those described in previous articles (Tomezzoli \& Pottier, 2016a), (Tomezzoli \& Pottier, 2016b), except for a hexagonal emplacement on its coverage. The nature of the emplacement is unclear because of the absence of a gun support. It is possible that it hosted either one or more telemeters or a radar Freya for distance measurements, or a light Flak gun, like a $2 \mathrm{~cm}$ Flak 30/38/Flakvierling or $3.7 \mathrm{~cm}$ Flak 18/36/37/43, or a heavier gun, like a $88 \mathrm{~mm}$ or a $105 \mathrm{~mm}$ gun mounted on its own support. Because of its elevated position, the telemeter would have had an unobstructed field of view and the possible gun would have been effective both against air and field targets. The $R 669$ combat room probably hosted an s.F.H. 25 rough howitzer or different gun. The $R 669$ combat room front and rear side apertures were closed, respectively, by a metallic, green coverage provided with a window and a wooden, brown double door, both not of origin; so that the combat room interior was not accessible. However, looking through the window, it was possible to ascertain that it was cluttered by materials. The ammunitions for the gun were stored in an ammunition room inside the R669. Because no stair was present on the external concrete structure, the hexagonal emplacement was accessible only through the combat room. The opening of the exhausted combat gas pipe was clearly recognizable on the bunker rear side. The $R 669$ external concrete structure was in a good preservation state without damages due to combats.

The $V f(2)$ (Figure 3), about $6 \times 4 \mathrm{~m}$, emerged about two meters from the terrain. It was provided with two entrances, only one of which provided with protection walls. A corridor, preserving its original wall pale ochre painting and ceiling white painting, connected the two entrances with the entrance of an interior single room. The entrances were obstructed by terrain and vegetation; so that the inspection of the interior was not possible. The absence on its coverage of chimney conduits suggested that this bunker was intended for storing materials rather than for hosting a group of soldiers. The emerging $V f(2)$ concrete structure was in a good preservation state without damages due to combats. 


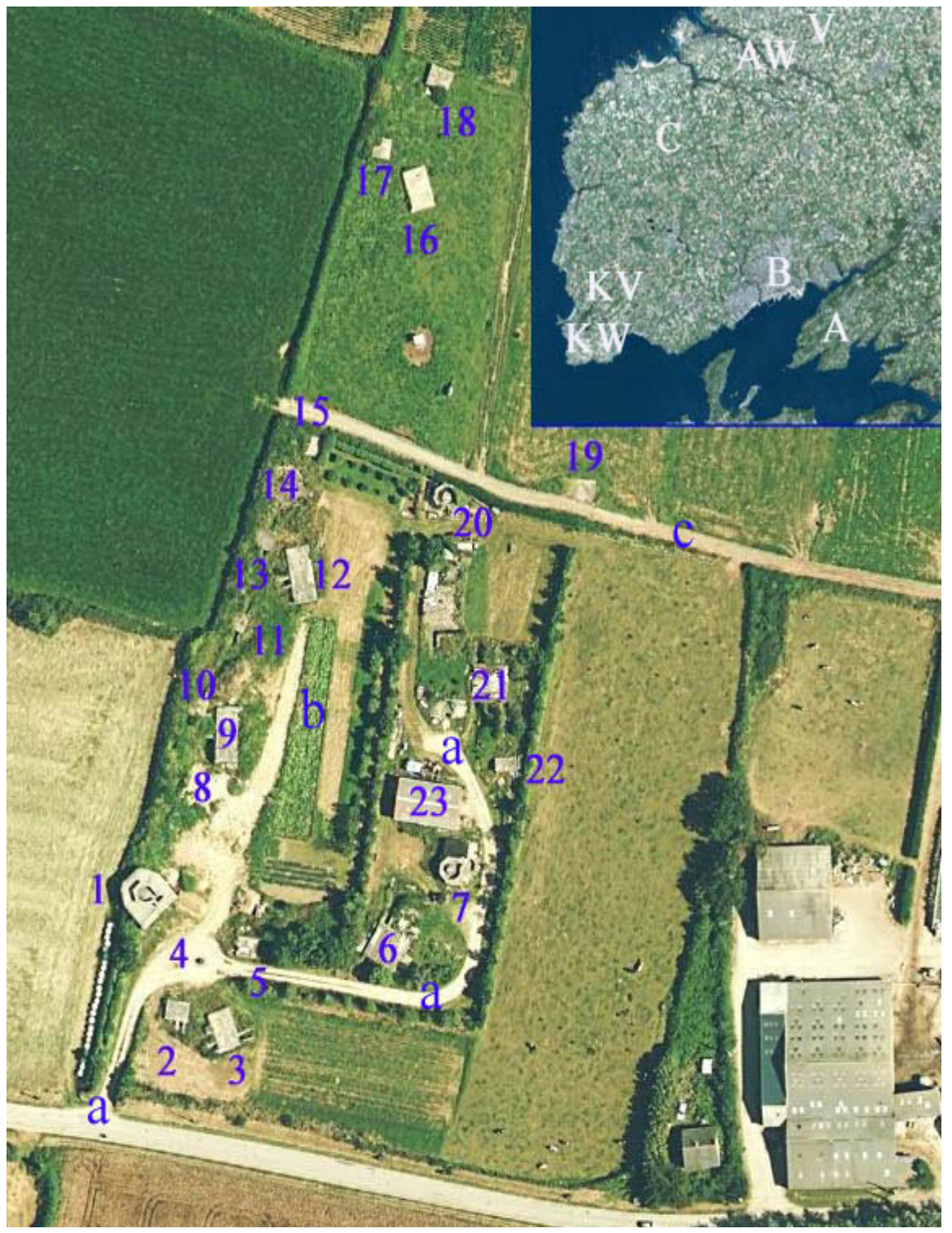

Figure 1. CleuzFoz heavy artillery battery-1 $R 669,2-3 V f s, 4$ open emplacement, $5 V f, 6$ M134, 7 Flak Vf; 8 open emplacement, 9 - 13 Vfs, 14 open emplacement, 15 - 18 Vfs, 19 possible bunker buried in the terrain, 20 FlakVf; $21 M 134,22 V f, 23$ agricultural shed; a access road, b central area, c external road; A Armorique peninsula; AW Aber Wrach; B Brest; C Cleus Foz battery; KW Keringar Wraz M. K. B. "Graf Spee”, KV Keringar Vihan base, V Vougo-Kerizoc radar base (Tomezzoli, 2016) [Geoportail].

The $V f(3)$ (Figure 4), about $9 \times 6 \mathrm{~m}$, emerged about two meters from the terrain. It was provided with two entrances, both provided with protection walls. A corridor, preserving its original wall pale ochre painting and ceiling white painting, connected the two entrances with the entrance of an interior single room. The entrances were obstructed by terrain and vegetation; so that the inspection of the interior was not possible. The presence on its coverage of two chimney conduits suggested that it was heated if necessary and therefore intended for hosting one or two groups of soldiers. The emerging $V f(3)$ concrete structure was in a good preservation state without damages due to combats. 


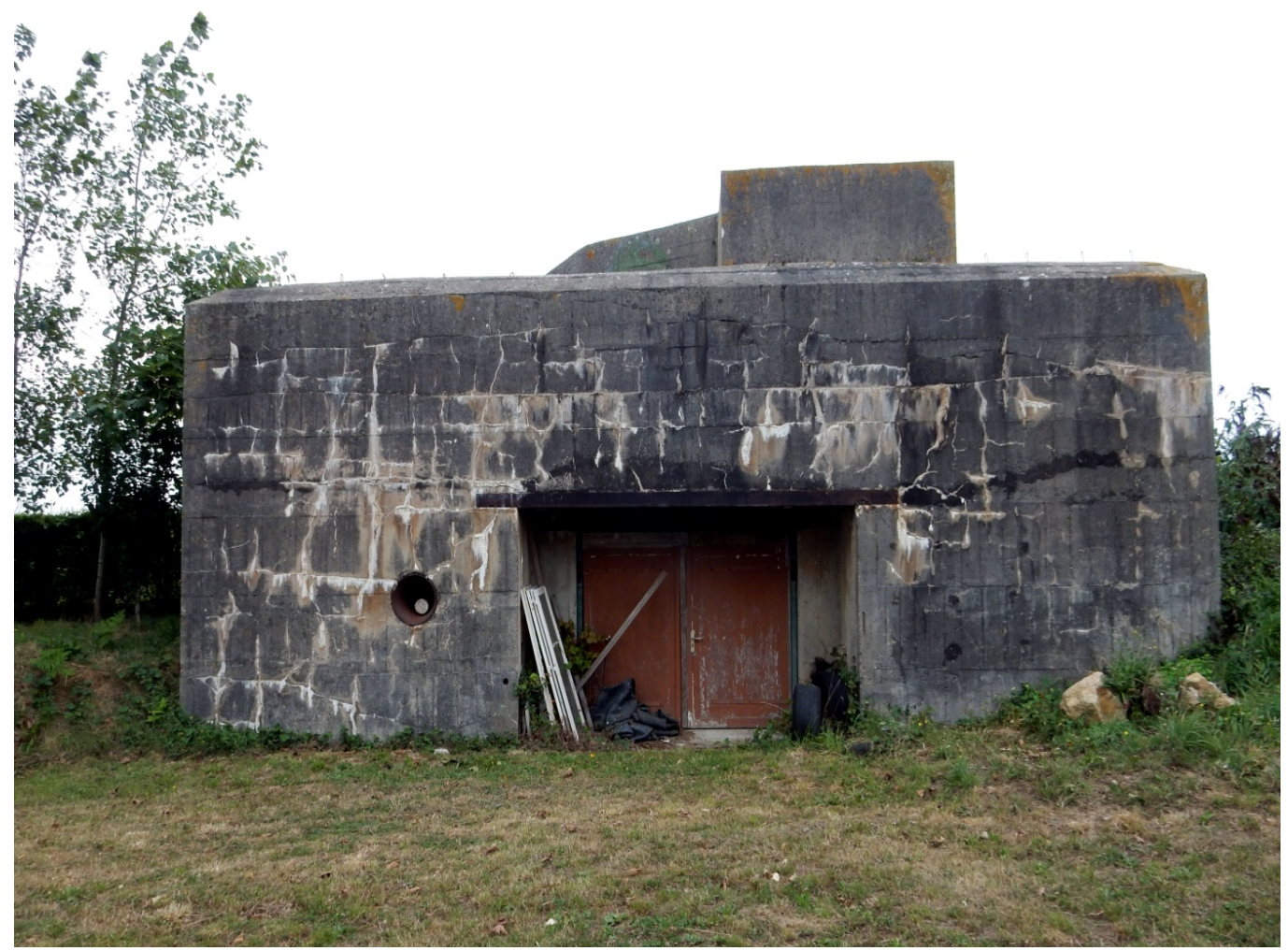

(1)

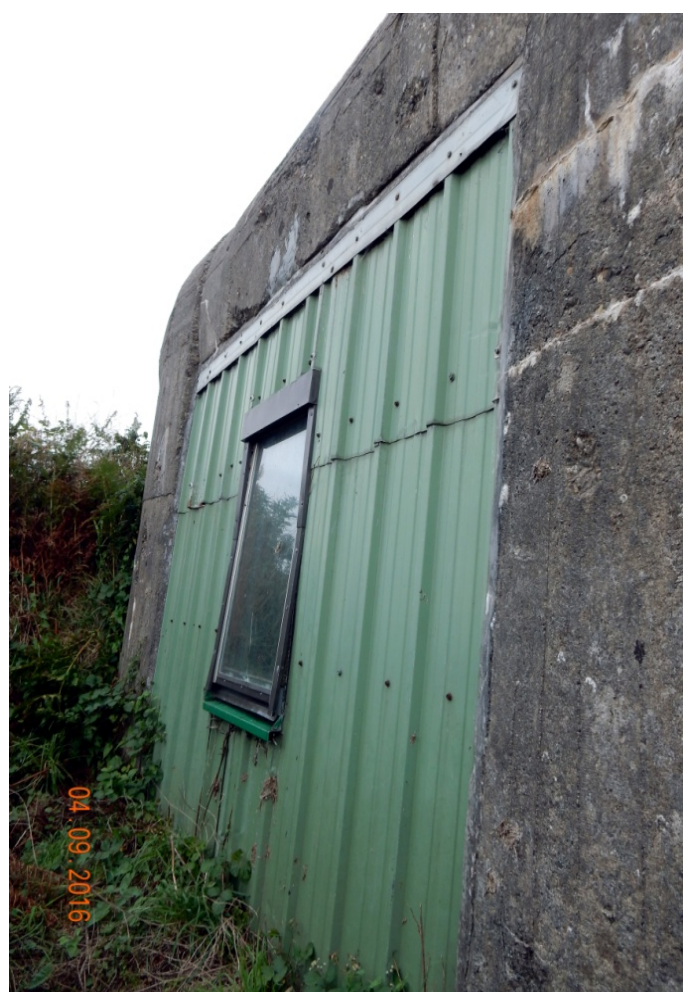

(2)

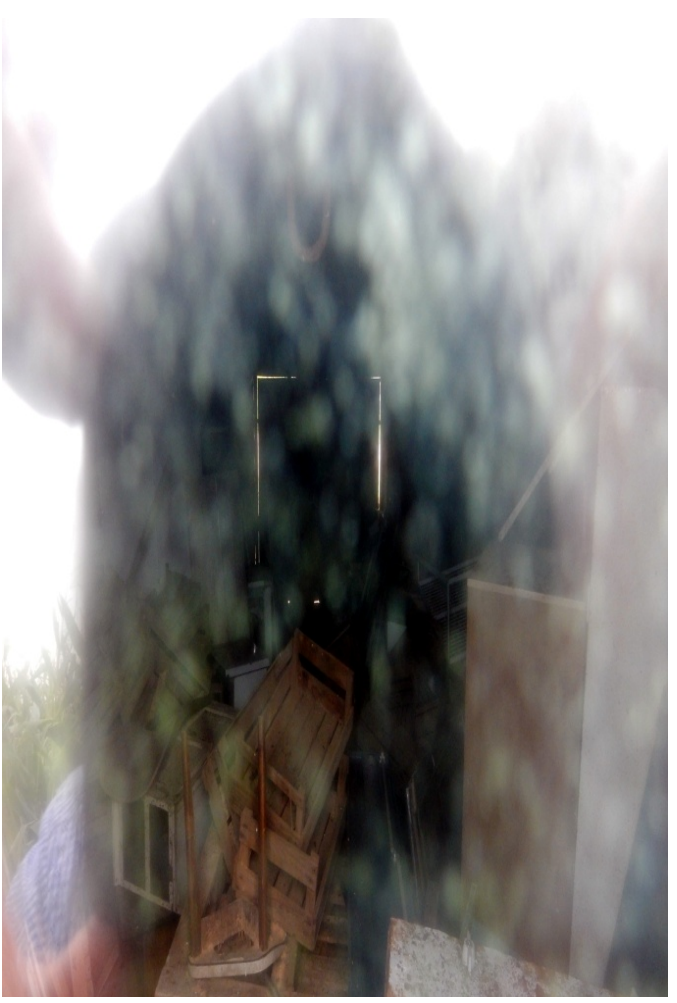

(3)

Figure 2. R669-(1) rear side opening of the combat room closed by a wooden, brown double door, not of origin, on the left opening of the exhausted combat gas pipe, (2) front side aperture of the combat room closed by a metallic, green coverage provided with a window, not of origin, (3) combat room interior cluttered by materials, seen through the window. 


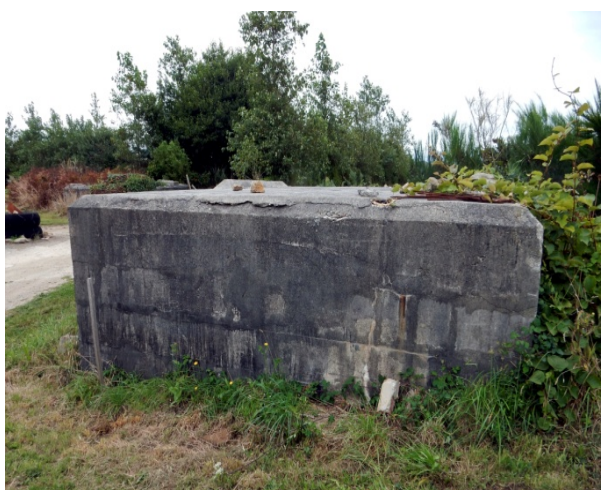

(1)

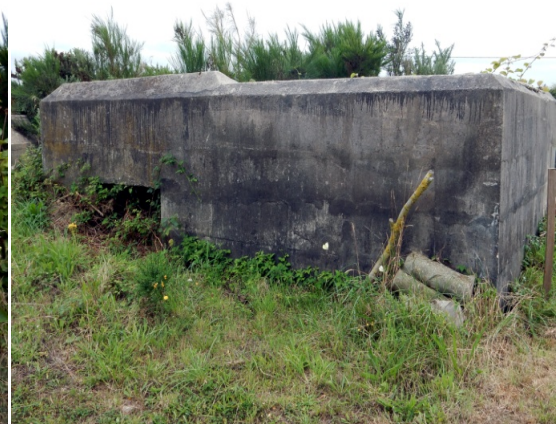

(2)

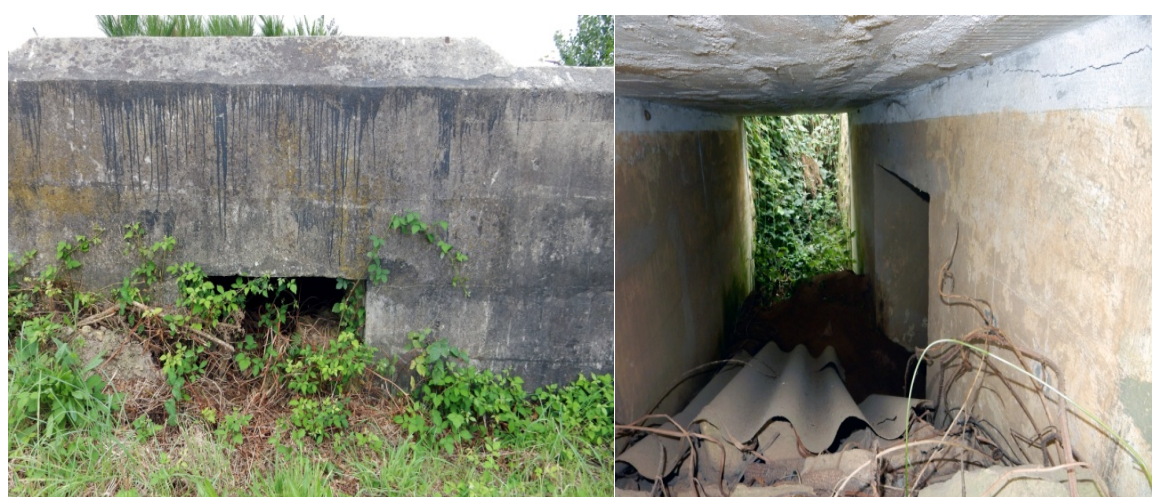

(3)

(4)

Figure 3. $V f(2)$-(1) side view, (2) side view, (3) entrance obstructed by terrain and vegetation, (4) corridor with interior single room entrance.

A circular open emplacement (4) about $10 \mathrm{~m}$ in diameter for s.F.H.25 rough howitzer (Figure 5) was located near the R669. It was composed by:

- an external circular, metallic rail about $20 \mathrm{~cm}$ wide and about $8 \mathrm{~m}$ in diameter, flanked by square cavities; and

- an internal, square $2 \times 2 \mathrm{~m}$ metallic plate provided with a raised metallic rim, a circular rail and, in the middle, a s.F.H.25 carriage rotation pin, about 40 $\mathrm{cm}$ height, covered by two tires. The presence of the rail, the rim and the rotation pin, excluded a use of the open emplacement for a projector or radar.

The $V f(5)$ (Figure 6), about $6 \times 4 \mathrm{~m}$, emerged about two meters from the terrain and was partially covered by vegetation. It was similar to $V f(2)$, provided with two entrances, both without protection walls. A corridor, preserving its original wall pale ochre painting and ceiling white painting, connected the two entrances with the entrance of an interior single room. The entrances were obstructed by terrain and vegetation; so that the inspection of the interior was not possible. The absence on its coverage of chimney conduits, suggests that this bunker was intended for storing materials. The emerging $V f(5)$ concrete structure was in a good preservation state without damages due to combats.

The location of the $V f(2), V f(3)$ and $V f(5)$ around the open emplacement (4) and near the $H 669$ suggested that they hosted material and servants for the guns installed on the open emplacement (4) and in the R669. 


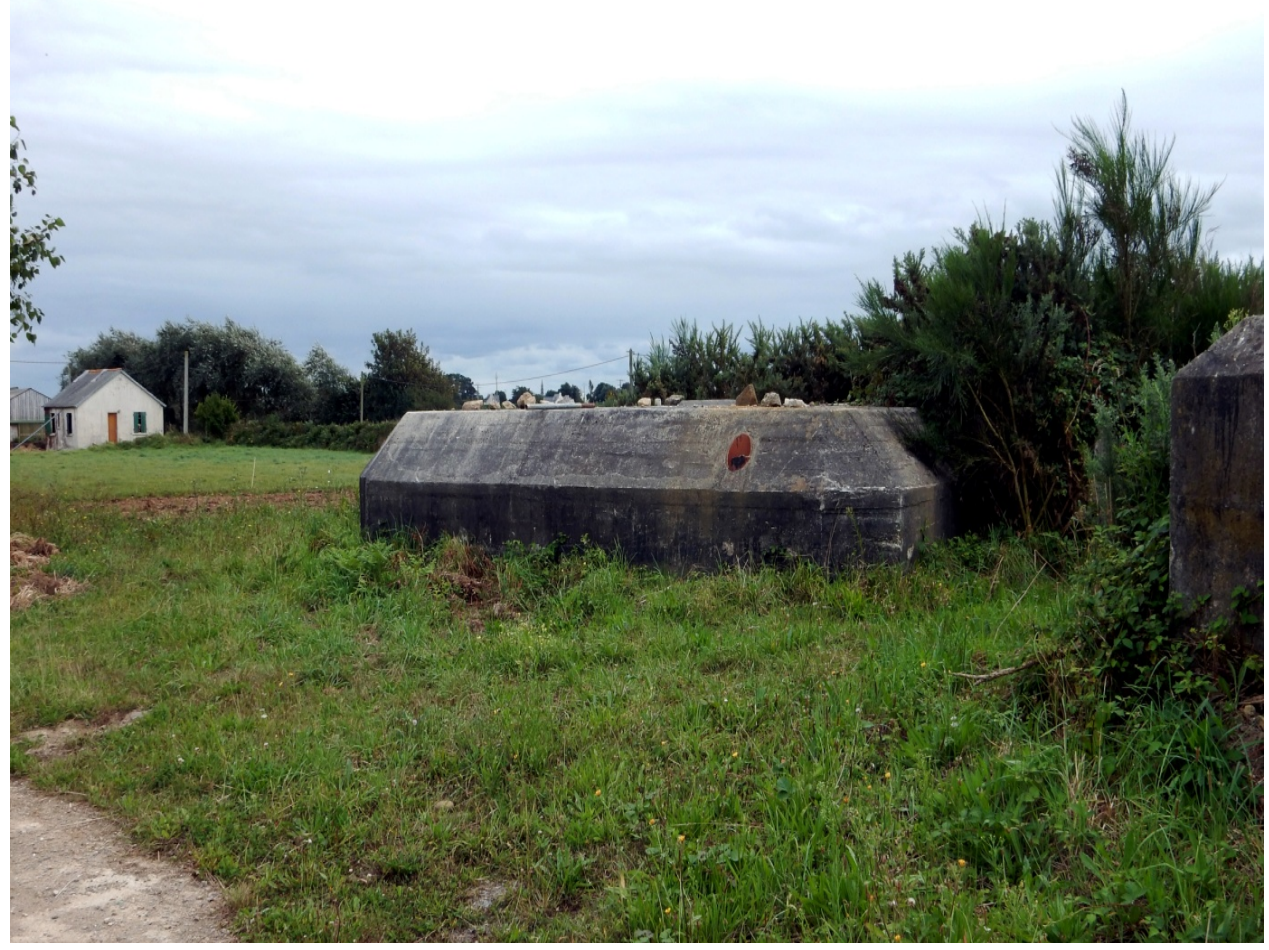

(1)

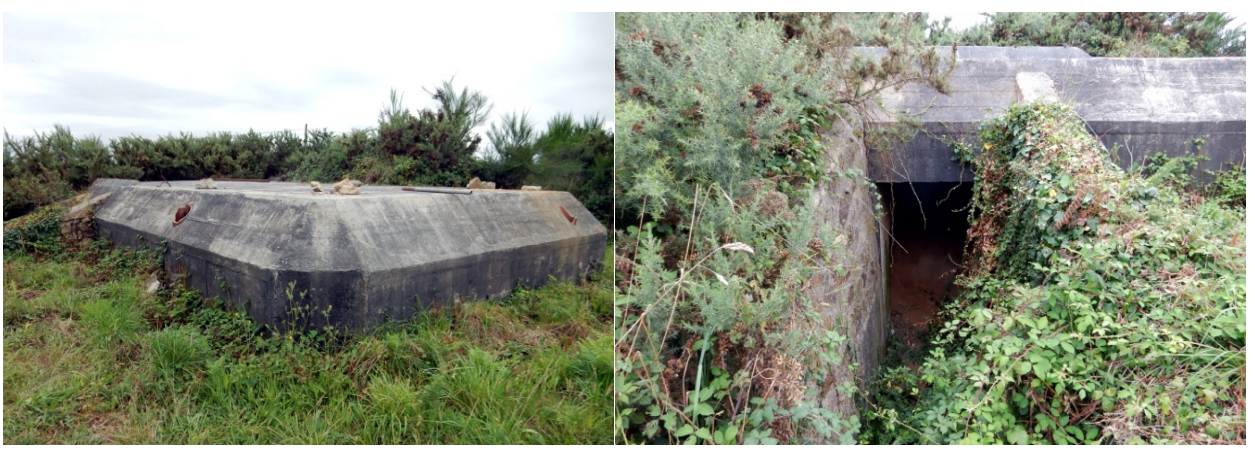

(2)

(3)

Figure 4. $V f(3)-(1)$ side view: on the coverage a chimney conduit, on the left circular open emplacement for S.F.H.25, on the right $V f(2)$, (2) coverage with two chimney conduits, on the left bunker entrance, (3) coverage $1 \mathrm{~m}$ thick and entrance obstructed by the vegetation.

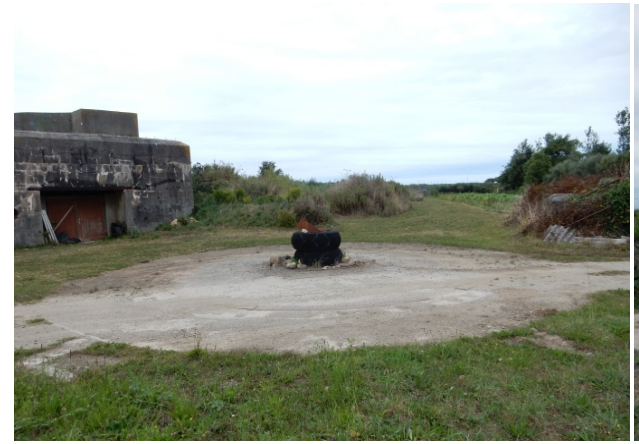

(1)

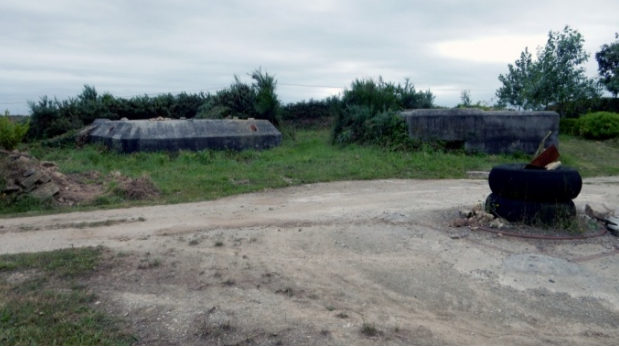

(2) 


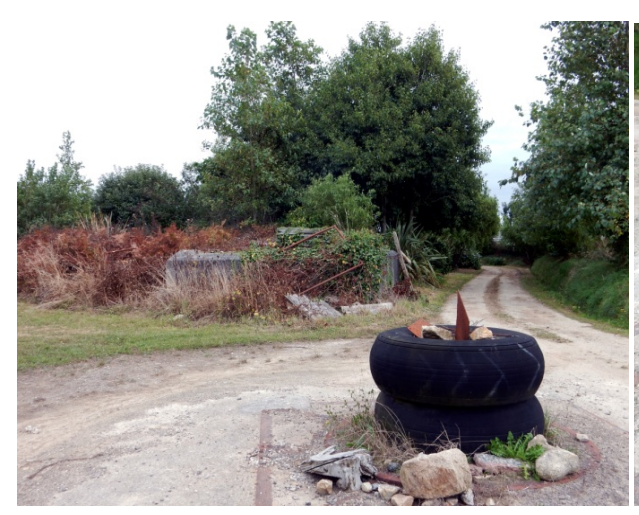

(3)

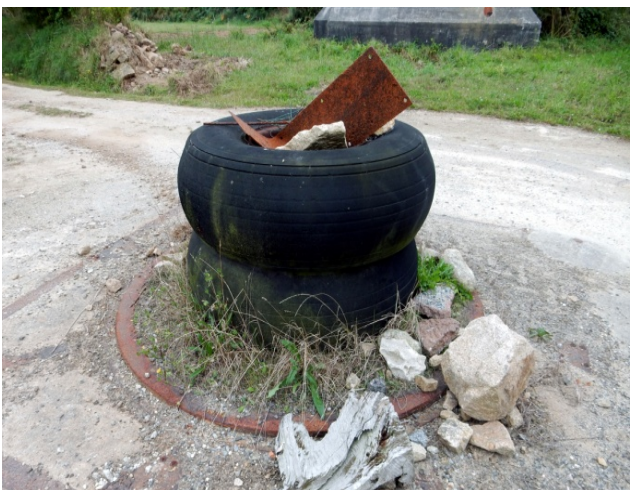

(4)

Figure 5. Open emplacement (4)-(1) general view: on the left $R 669$, on the right $V f(5),(2)$ on the left $V f(3)$, side view: on the right $V f(2)$, (3) side view: on the left $V f(5)$, on the right access road of the site, (4) square metallic plate provided with raised metallic rim, circular rail and carriage rotation pin covered by two tires.

The M134 (6) (Figure 7), $11.10 \times 10.80 \mathrm{~m}$, emerged about one meter from the terrain. It was provided with two entrances, both provided with a concrete access ramp and protection walls. A corridor connected the two entrances with the entrances of two interior ammunition rooms. The bunker entrances were obstructed by terrain and vegetation; so that the inspection of its interior was not possible. Because of its function of storing ammunitions, it was located relatively far from the $R 669$ and the open emplacement (4) (Figure 1). The emerging M134 (6) concrete structure was in a good preservation state without damages due to combats.

The Flak $V f(7)$ (Figure 8) $\left(48^{\circ} 35^{\prime} 0.36^{\prime \prime} \mathrm{N}, 4^{\circ} 33^{\prime} 0.07^{\prime \prime} \mathrm{W}\right)$ was formed by a concrete, inferior, cubic section, about $5 \times 5 \mathrm{~m}$, supporting a concrete, hexagonal gun emplacement. The gun emplacement was accessible through a spiral staircase provided with a concrete bricks protection wall. On the front side, leaned on the cubic section was a concrete annexed room. Its walls and coverage had a thickness of about $20 \mathrm{~cm}$ and a portion of them collapsed by structural reasons. On the rear side was the entrance provided with protection walls. The bunker inside was cluttered by materials and apparently all the original bunker furniture disappeared. The hexagonal gun emplacement preserved the ammunition niches and a concrete octagonal gun support. On the support no joint for fixing a gun, but rather a mosaic, probably of origin, showing an anti-aircraft gun, probably an 88 $\mathrm{mm}$ or a $105 \mathrm{~mm}$ gun with the inscription CleusFos and a mast of a small Aeolian generator. The kind of Flak gun hosted in the emplacement is unknown, but probably it was a light one like a $2 \mathrm{~cm}$ Flak 30/38/Flakvierling or $3.7 \mathrm{~cm}$ Flak 18/36/37/43. On the external FlakVf (7) bunker concrete structure the traces of the boards of the formwork were clearly visible. It was in a substantial good preservation state without damages due to combats, with the only exception of the collapsed portion of the annexed room. 


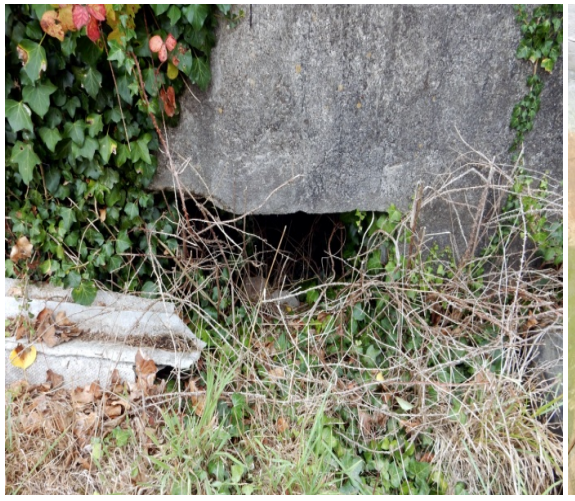

(1)

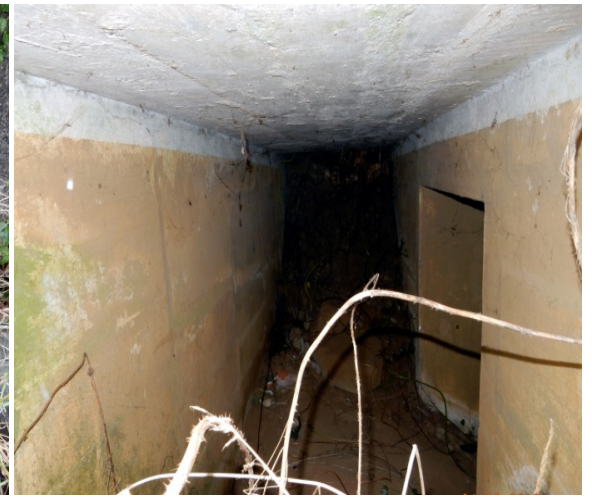

(2)

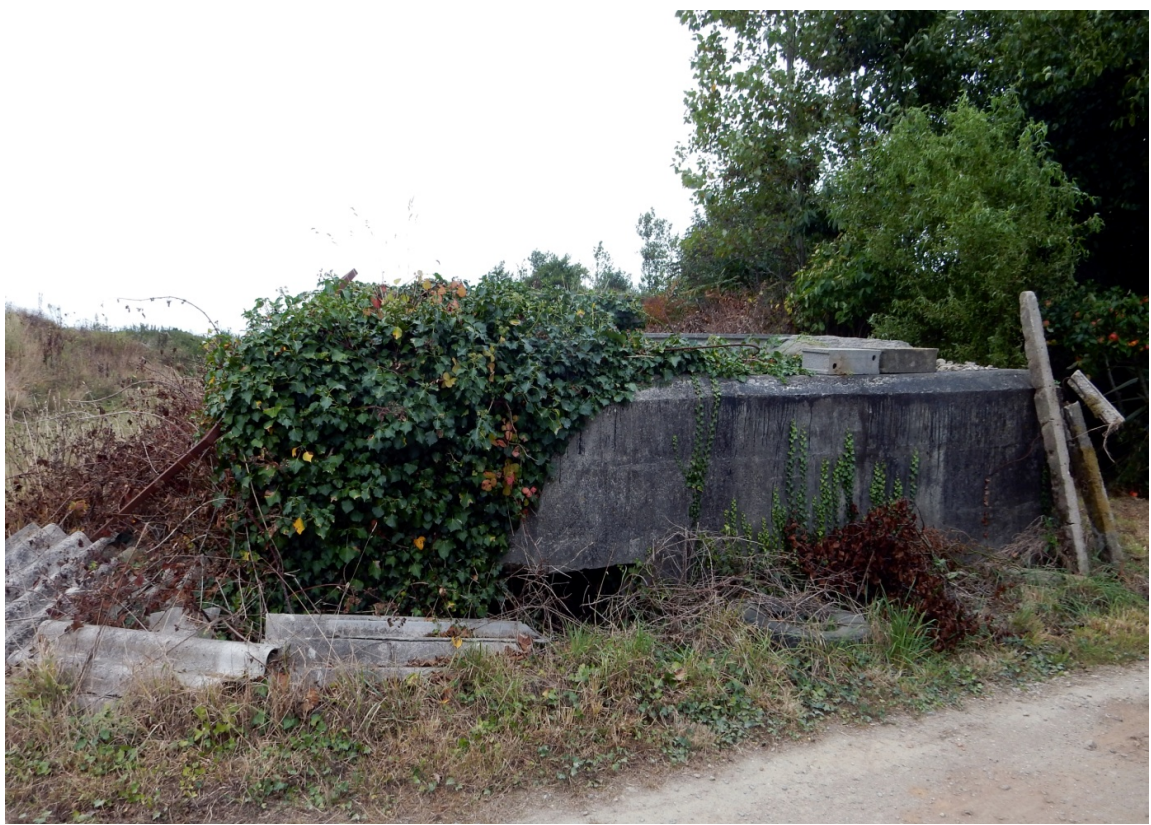

(3)

Figure 6. $V f(5)-(1)$ entrance obstructed by terrain and vegetation, (2) internal corridor with interior single room entrance, (3) complete view.

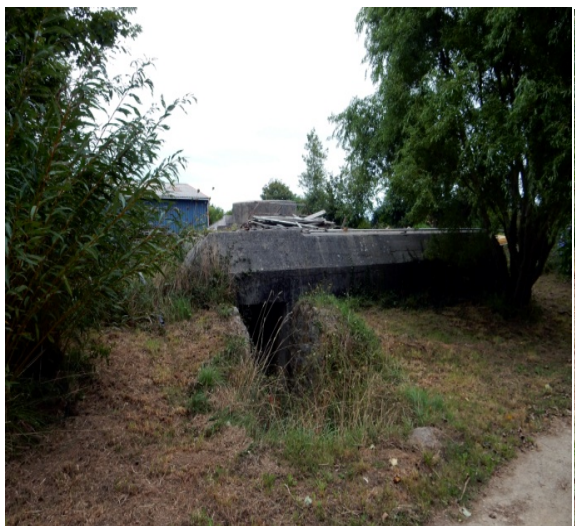

(1)

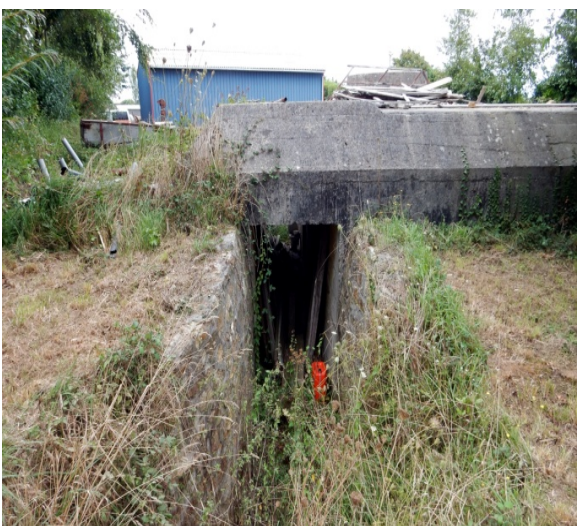

(2)

Figure 7. M134 (6)-(1) emerging portion with entrance, (2) entrance having protection walls and access ramp obstructed by vegetation, on the foreground the agricultural shed (23). 


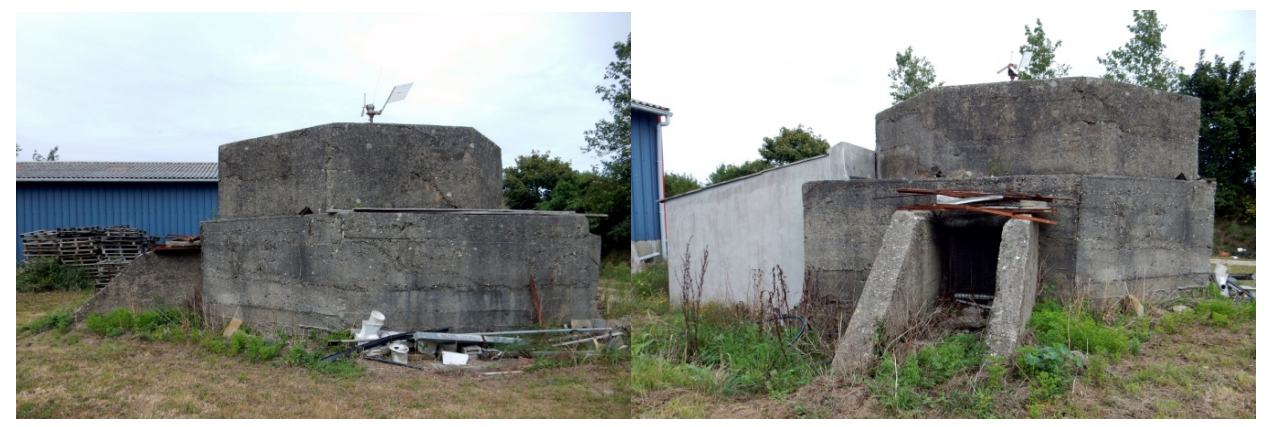

(1)

(2)

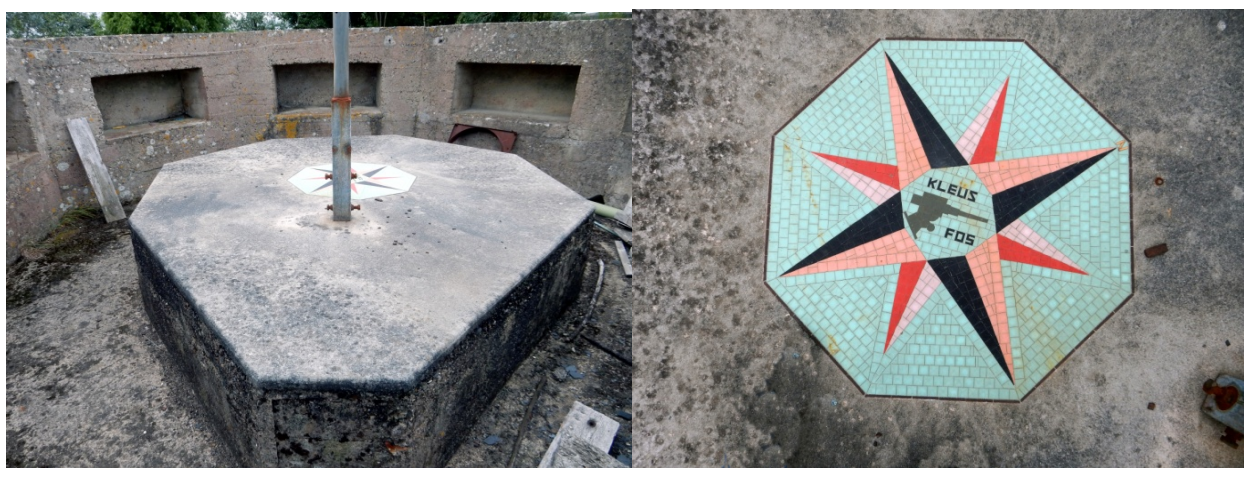

(3)

(4)

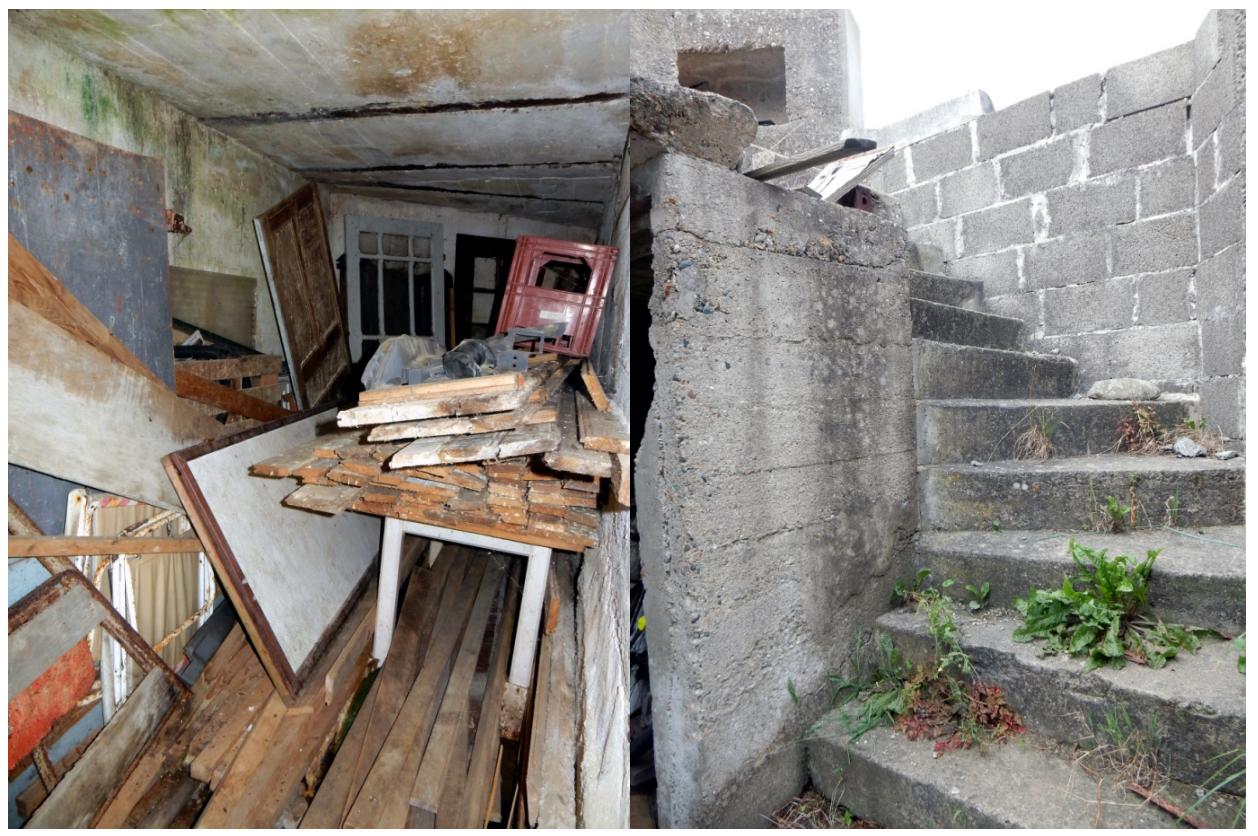

(5)

(6) 


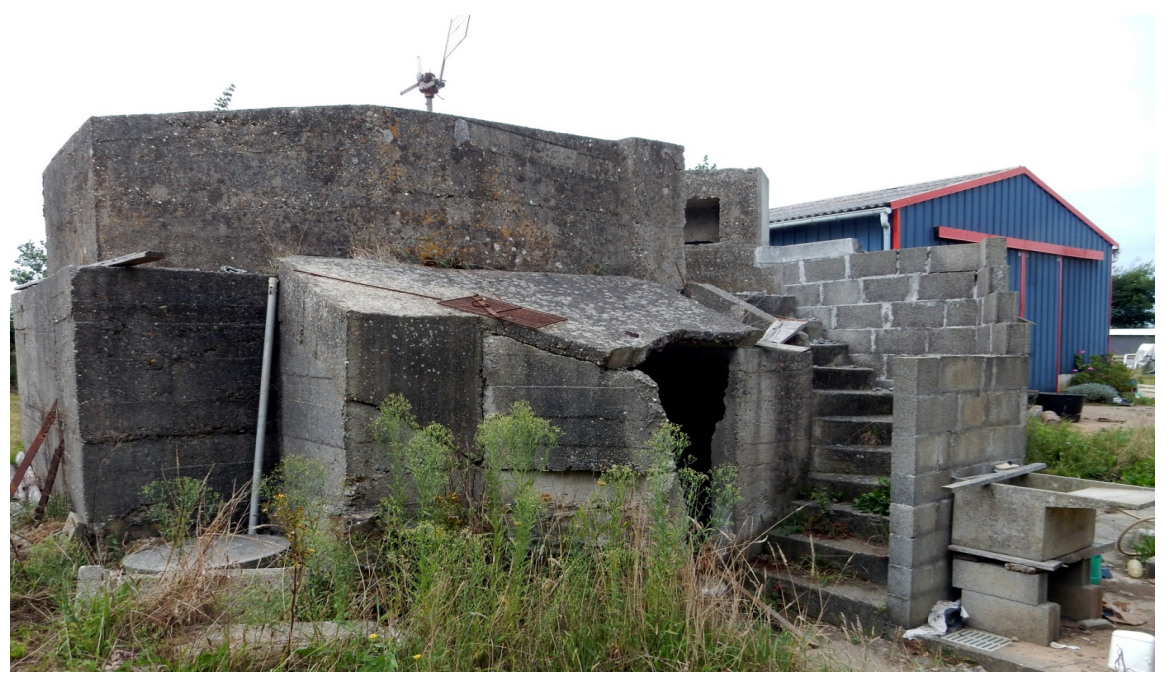

(7)

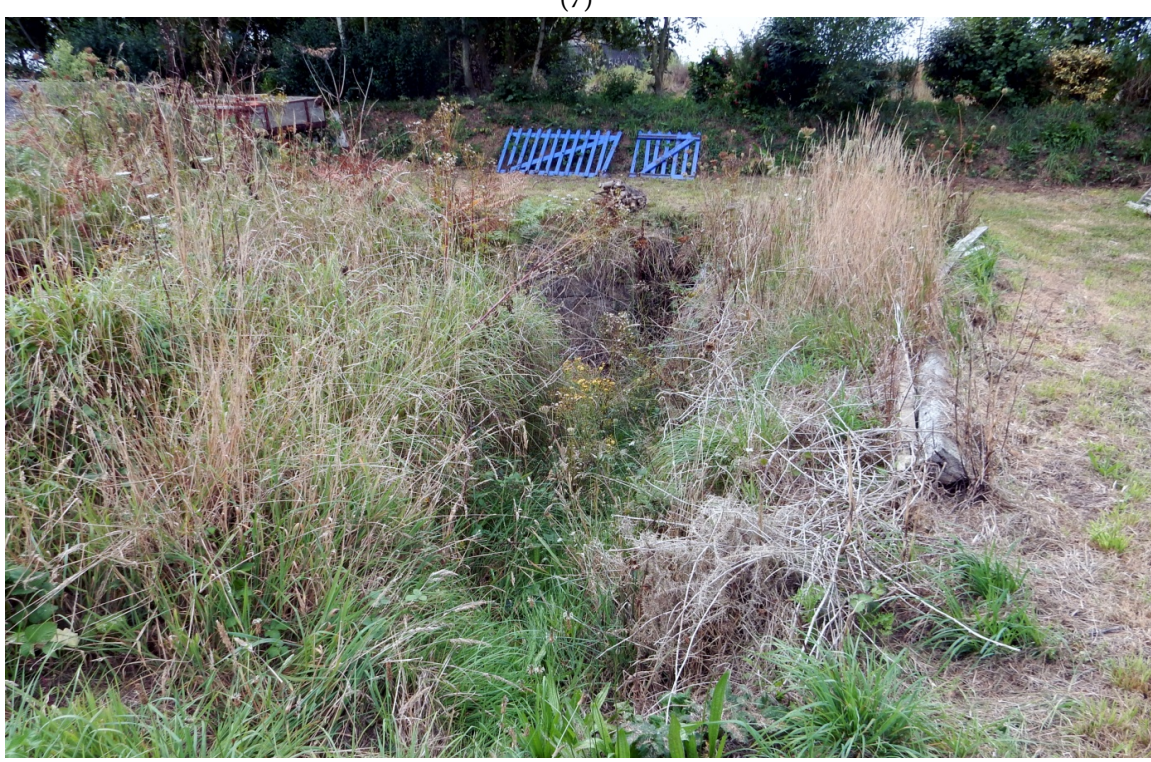

(8)

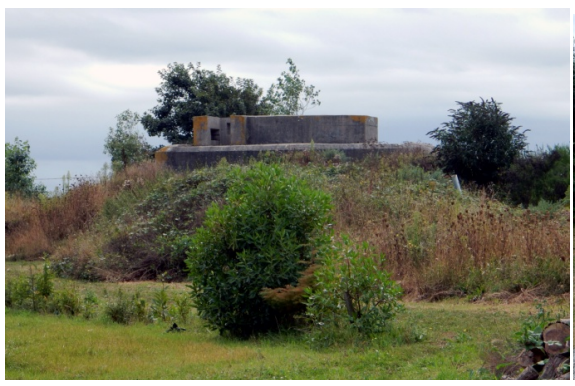

(9)

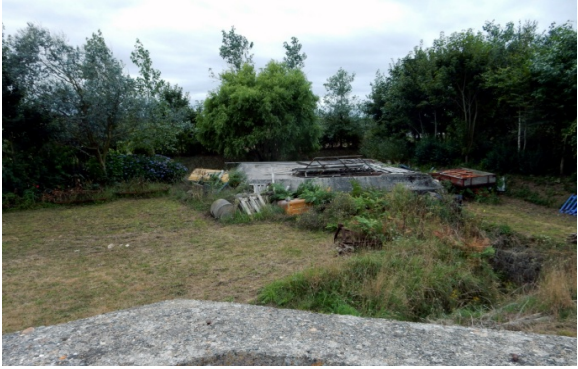

(10)

Figure 8. Flak $V f(7)-(1)$ concrete, cubic section with superimposed hexagonal gun emplacement, (2) entrance with protective walls, on the left small shed leaning on the bunker, (3) octagonal gun support with mosaic and mast of a small Aeolian generator, on the foreground ammunitions niches, (4) mosaic probably of origin, (5) bunker inside cluttered by materials, (6) staircase to the hexagonal emplacement, (7) front side: annexed concrete room and access stair, on the top the small Aeolian generator, on the right the agricultural shed (23), (8) access ramp to a buried bunker near the Flak Vf(7), (9) R669 with hexagonal emplacement, (10) $V f(8)$ near to the gun emplacement (8). 
A possible circular open gun emplacement (8) (Figure 1) was located about $30 \mathrm{~m}$ north from the circular open emplacement (4). It measured about $10 \mathrm{~m}$ in diameter. The external circular rail, the metallic plate, the circular rail and the S.F.H.25 carriage rotation pin were not visible, suggesting that the emplacement was not terminated or not foreseen for an s.F.H.25 but rather for an $88 \mathrm{~mm}$ or $105 \mathrm{~mm}$ gun mounted on its own support.

The $V f(9)$ (Figure 1), about $12 \times 6 \mathrm{~m}$, emerged two meters from the terrain. It was provided with one entrance provided with protection walls. The entrance was obstructed by terrain and vegetation; so that the inspection of the interior was not possible. The presence on its coverage of two chimney conduits suggested that it was intended for hosting one or two groups of soldiers. The emerging $V f(9)$ concrete structure was in a good preservation state without damages due to combats.

The $V f(10)$ (Figure 1), about $5 \times 5 \mathrm{~m}$, was buried in the terrain. It was provided with one entrance provided with protection walls. The entrance was obstructed by terrain and vegetation; so that the inspection of its interior was not possible. The absence on its coverage of conduits for chimneys, suggested that it was intended for storing materials for the gun at the open emplacement (8).

The location of the $V f(9)$ and $V f(10)$ near the open emplacement (8) suggested that they hosted material and servants for the gun installed on the open emplacement (8).

The $V f(11)$ (Figure 1), about $4 \times 4 \mathrm{~m}$, was buried in the terrain. It was provided with two entrances, both with a concrete access ramp and protection walls. The entrances were obstructed by terrain and vegetation; so that the inspection of its interior was not possible. Notwithstanding its reduced dimensions, its location in the middle of the bunker and emplacements 1 - 5, 8 - 10, 12 - 15 (Figure 1) suggests a possible function of direction of the fire operations of the battery.

The $V f(12)$ (Figure 9), about $12 \times 6 \mathrm{~m}$, emerged about two meters from the terrain and was partially covered by piles of firewood. It was similar to $V f(9)$, provided with one entrance provided with protection walls. The entrance was obstructed by terrain and vegetation; so that the inspection of its interior was not possible. The presence on its coverage of two chimney conduits suggested that it was intended for hosting one or two groups of soldiers. The emerging $V f(12)$ concrete structure was in a good preservation state without damages due to combats.

The $V f(13)$ (Figure 1), about $4 \times 4 \mathrm{~m}$, was buried in the terrain. It was similar to $V f(11)$, provided with two entrances, both provided with a concrete access ramp and protection walls. The ramps were aligned with those of $V f(11)$. The entrances were obstructed by terrain and vegetation; so that the inspection of its interior was not possible.

A circular open emplacement (14) for s.F.H.25 rough howitzer (Figure 10) was located near the $V f(12)$ and $V f(13)$. It measured about $10 \mathrm{~m}$ in diameter. The internal, square $2 \times 2 \mathrm{~m}$ metallic plate, the circular rail and the s.F.H. 25 carriage rotation pin were covered by a pile of firewood and therefore not visible. Only a portion of the external circular rail, about $20 \mathrm{~cm}$ wide, flanked by square 
cavities was visible.

The $V f(15)$ (Figure 1 and Figure 11), about $5 \times 5 \mathrm{~m}$, emerged about two meters from the terrain and was partially covered by vegetation. Its entrance/s did not emerge from the terrain; so that the inspection of its interior was not possible. The absence on its coverage of chimney conduits suggested that it was intended for storing materials for the s.F.H.25 rough howitzer at the open emplacement (14). The emerging $V f(15)$ concrete structure was in a good preservation state without damages due to combats.

The location of the $V f(12), V f(13)$ and $V f(15)$ around the open emplacement (14) suggested that they hosted material and servants for the s.F.H.25 howitzer installed on the open emplacement (14).

The $V f(16)$ (Figure 1 and Figure 11), about $9 \times 6 \mathrm{~m}$, emerged about two meters from the terrain. It was similar to $V f(3)$, its entrances were obstructed by terrain and vegetation; so that the inspection of its interior was not possible. It was probably intended for hosting one or two groups of soldiers. The emerging $V f(16)$ concrete structure was in a good preservation state without damages due to combats.

The $V f(17)$ (Figure 1 and Figure 11), about $4 \times 4 \mathrm{~m}$, emerged about two meters from the terrain. It was similar to $V f(11)$ and $V f(13)$, its entrances were obstructed by terrain and vegetation; so that the inspection of its interior was not possible. The emerging $V f(17)$ concrete structure was in a good preservation state without damages due to combats.

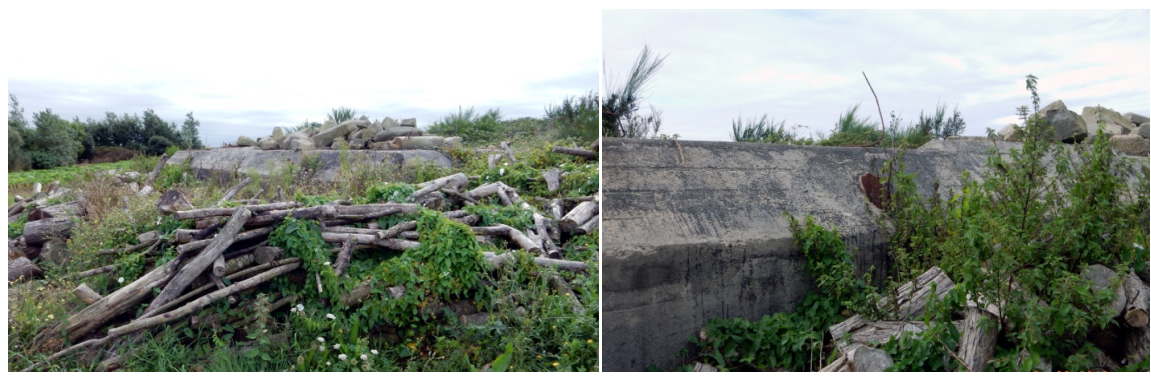

(1)

(2)

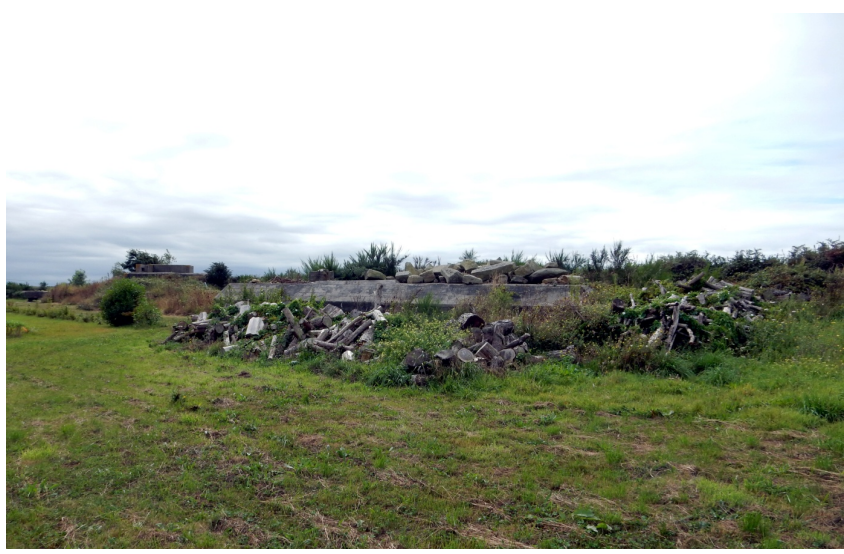

(3)

Figure 9. $V f(12)-(1)$ side view, (2) coverage with chimney conduit, (3) complete view, on the left $R 669$. 
The $V f(18)$ (Figure 1 and Figure 11), about $6 \times 4 \mathrm{~m}$, emerged about two meters from the terrain and was partially covered by vegetation. It was similar to $V f$ (2), provided with entrances obstructed by terrain and vegetation; so that the inspection of its interior was not possible. The absence on its coverage of chimney conduits, suggested that it was intended for storing materials. The emerging $V f(18)$ concrete structure was in a good preservation state without damages due to combats.

The location of the $V f(16), V f(17)$ and $V f(18)$ around a circular area about $10 \mathrm{~m}$ in diameter suggested the existence of a further possible circular open gun emplacement not terminated or not foreseen for an S.F.H.25 but rather for an 88 mm or $105 \mathrm{~mm}$ gun mounted on its own support.

An area of $7.50 \times 5.50 \mathrm{~m}$ near an external road (c) indicated the possible presence of a buried bunker (19).

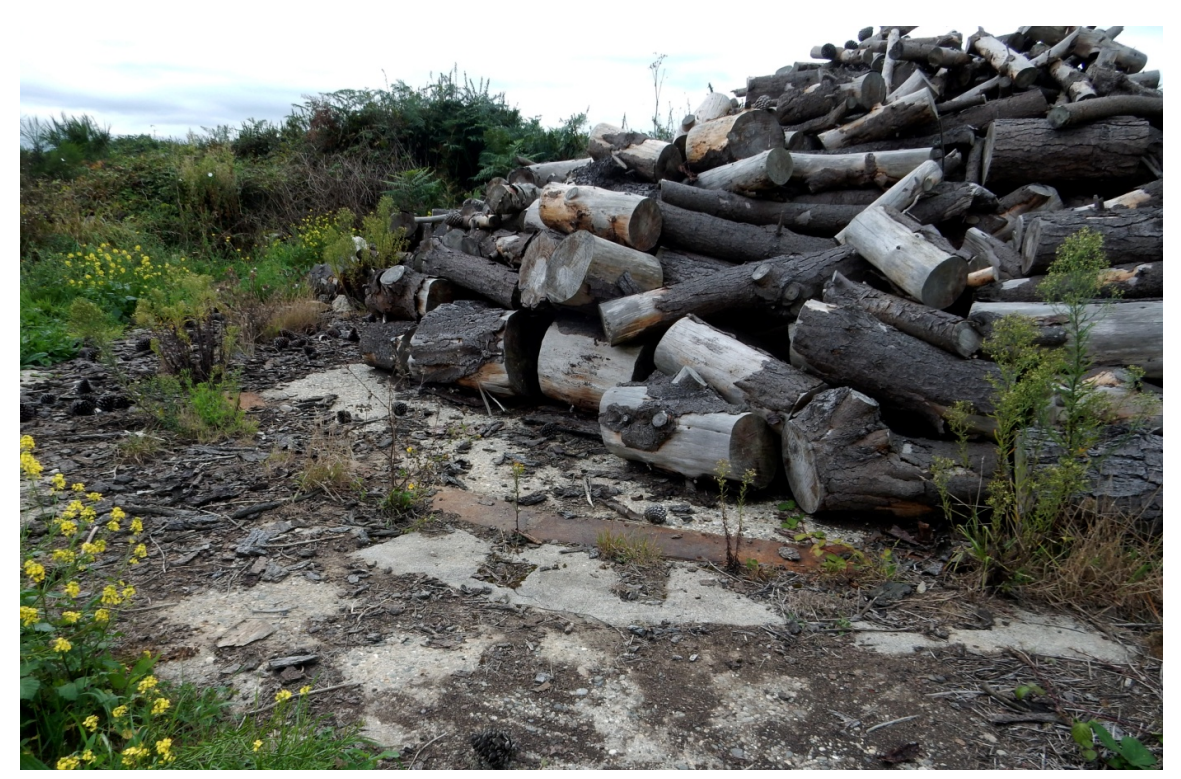

Figure 10. Open gun emplacement (14), in the middle external circular rail and square cavities.

The Flak Vf $(20)$ (Figure 12$)\left(48^{\circ} 35^{\prime} 3^{\prime \prime} \mathrm{N}, 4^{\circ} 33^{\prime} 0.12^{\prime \prime} \mathrm{W}\right)$ was integrated in a poultry house. It was similar to Flak $V f(7)$ but of poorer construction. It was built integrally with local stone bricks. A circular inferior section having a circular internal room supported a hexagonal gun emplacement. Its walls and coverage had small thick of about $40 \mathrm{~cm}$ and a portion of them collapsed by structural reasons. The hexagonal gun emplacement preserved the concrete gun support and the ammunition niches. The kind of Flak gun hosted in the emplacement is unknown, but probably it was a light one like a $2 \mathrm{~cm}$ Flak 30/38/Flakvierling or $3.7 \mathrm{~cm}$ Flak 18/36/37/43. The external bunker concrete structure was in a substantial good preservation state, with the exception of the collapsed portion, without damages due to combats.

The $M 134$ (21) (Figure 13), $11.10 \times 10.80 \mathrm{~m}$, was buried in the terrain. It was provided with two entrances, both with access ramp and protection walls. A cor- 
ridor, preserving its original wall pale ochre painting and metallic ceiling, connected the two entrances with the entrances of two interior ammunition rooms. The corridor entrances were not obstructed; so that the inspection of its interior was possible. Each ammunition room preserved the white painting of the walls, the metallic ceiling and a wooden door probably of origin. All the original room furniture disappeared and their interior was cluttered by materials. Because of its function of storing ammunitions, it was located relatively far from the $R 669$ and the open emplacements (Figure 1).

The $V f(22)$ (Figure 14), about $5.5 \times 3.5 \mathrm{~m}$, was buried in the terrain. It was provided with an entrance provided with access ramp without protection walls. The entrance was obstructed by vegetation, so that the inspection of its interior was not possible. Its coverage had small thick of about $30 \mathrm{~cm}$. Its reduced dimensions and light coverage (Figure 12) suggested for it a secondary but important function, like that of water source protection or latrine.

An accurate search on the central area (b) provided no evidence of possible disappeared wooden barracks hosting battery services like a radio station, further soldiers' lodgments, one or more canteens, one or more kitchens, cinema, douches and latrines.

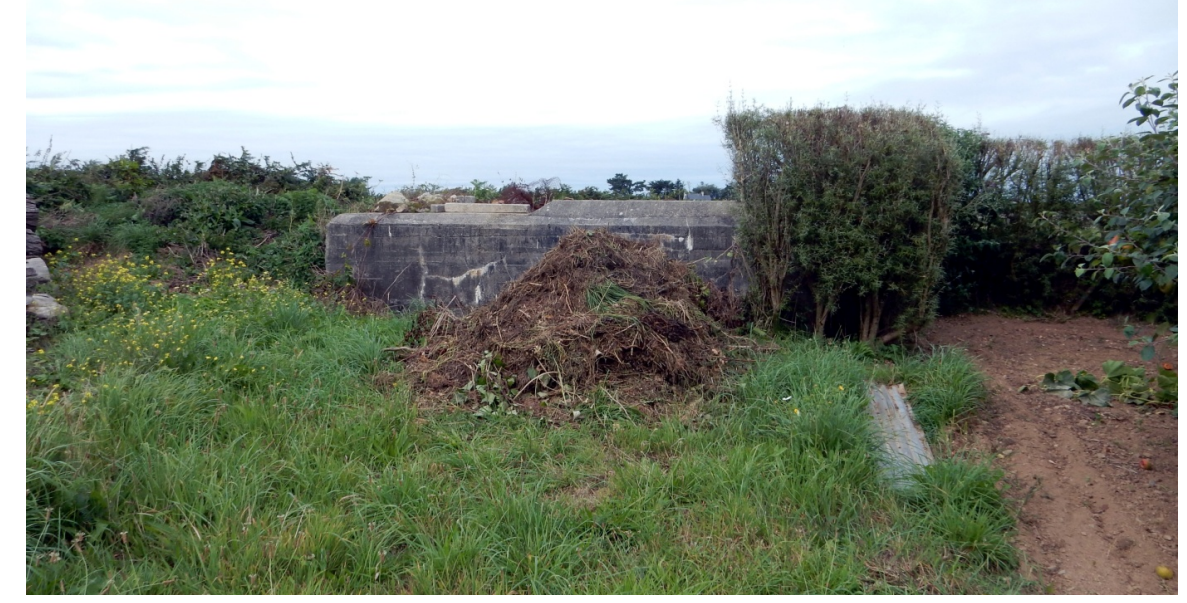

(1)

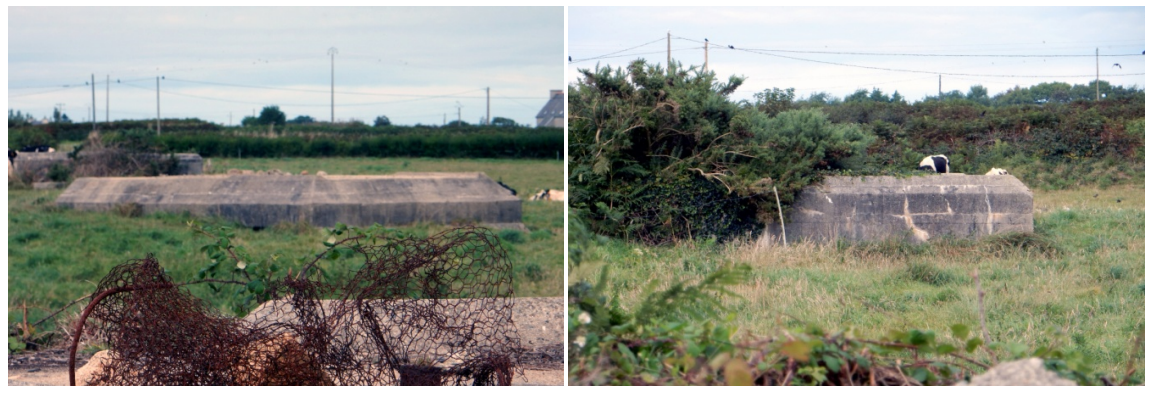

(2)

(3)

Figure 11. Bunkers-(1) $V f(15),(2) V f(16)$, on the left $V f(17)$ and $V f(18),(3) V f(17)$. 


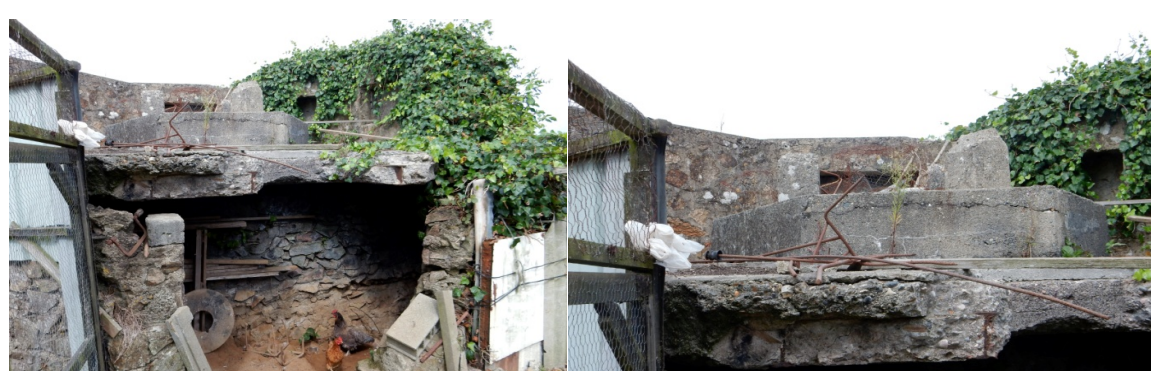

(1)

(2)

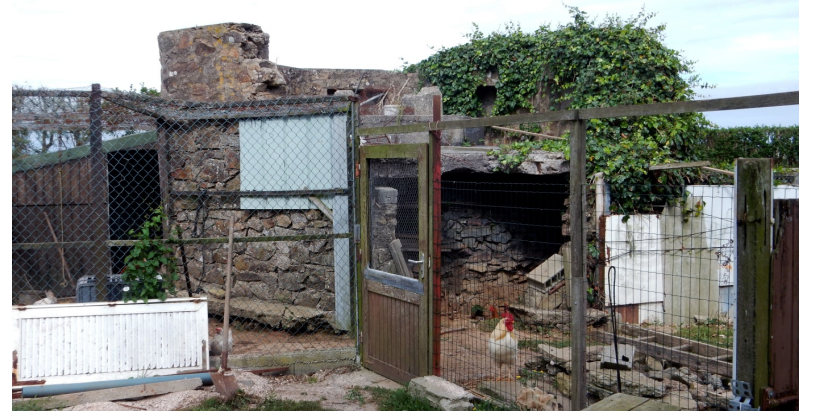

(3)

Figure 12. Flak $V f(20)$-(1) circular inferior section in local stone bricks, (2) circular internal room, (3) hexagonal gun emplacement: concrete gun support and on the foreground ammunitions niche.

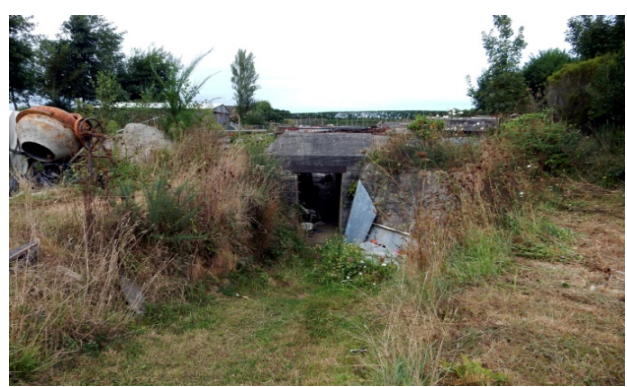

(1)

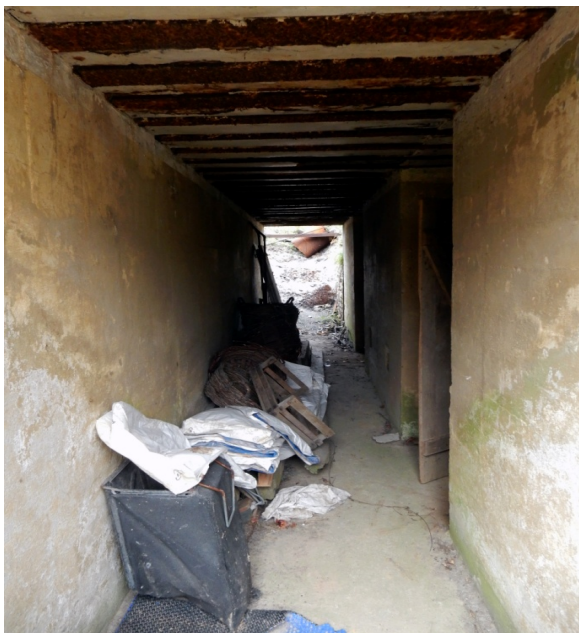

(3)

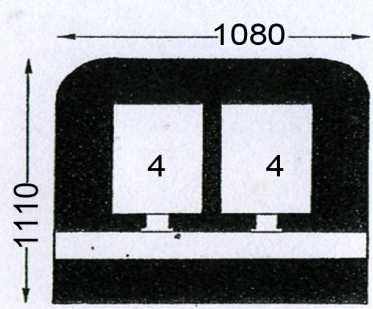

(2)

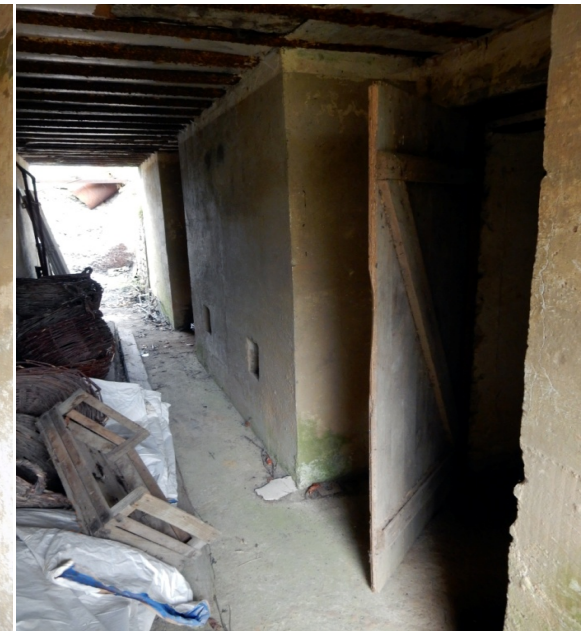

(4) 


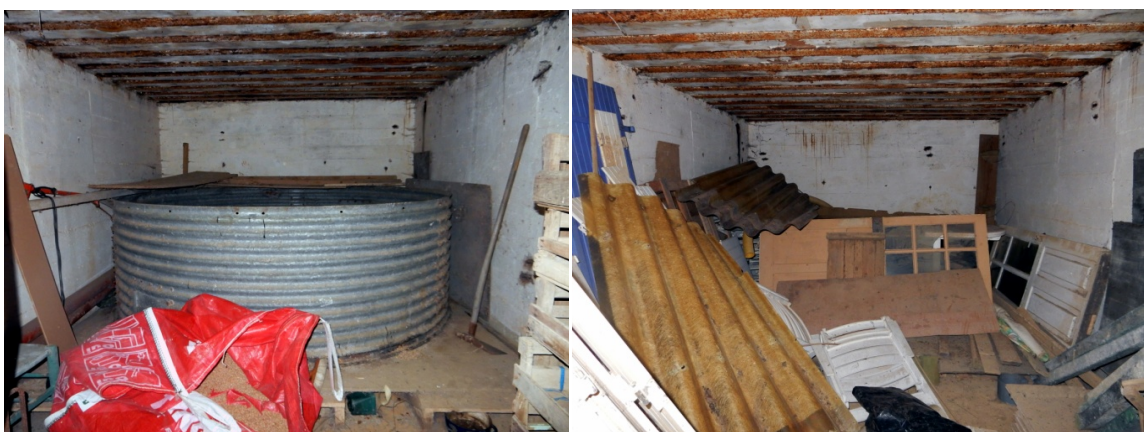

(5)

(6)

Figure 13. M134 (21)-(1) entrance with concrete access ramp and protection walls, (2) M134 plan: 4 ammunition room (Rudi 1988), (3) corridor with ammunition room entrances and metallic ceiling, (4) room door, (5) ammunition room, (6) ammunition room.

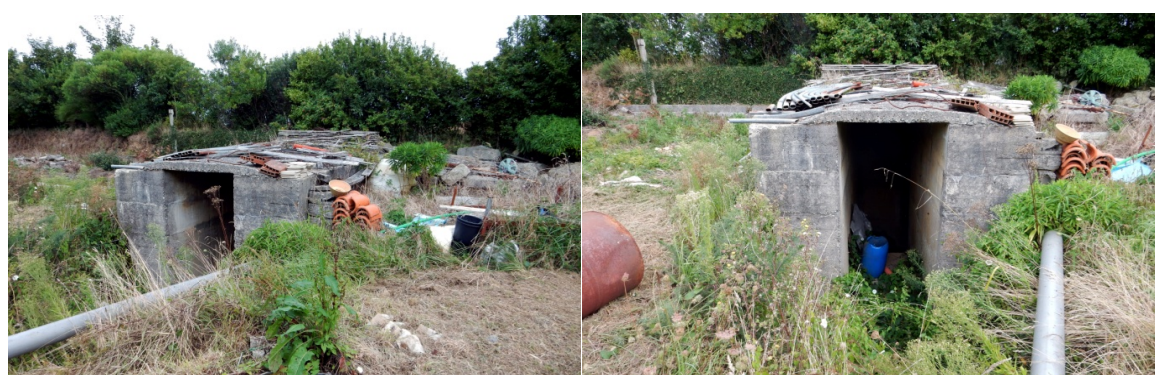

(1)

(2)

Figure 14. $V f(22)$-(1) entrance with access ramp without protection walls, (2) entrance obstructed by vegetation.

\section{The Battery Organization}

On the basis of the above description, the organization of the battery can be tentatively traced out as follows. The $R 669$ (1) and the open emplacements (4), (8), (14) were disposed along a line north-south on the east side of the battery. The $150 \mathrm{~mm}$ s.F.H.25 in the R669 (1) was protected against air and field attacks but its shooting range was restricted to the direction of Landeda for its defence or for its bombardment. The s.F.H.25s and/or guns in the open emplacements (4), (8), (14) were exposed to air and field attacks but their shooting range was unrestricted. The $V f(2), V f(3)$ and $V f(5)$ hosted materials and servants of the s.F.H.25 at the open emplacement (4) and the gun in the $R 669$ (1). The $V f(9)$ and $V f(10)$ hosted respectively materials and servants of the s.F.H.25 or gunat the open emplacement (8). The $V f(12), V f(13)$ and $V f(15)$ hosted materials and servants of the s.F.H.25 at the open emplacement (14). The $V f(16), V f(17)$ and $V f(18)$, hosted materials and servants of the s.F.H.25 or gun at a possible open emplacement to be constructed or which was buried in the terrain. Two or three $V f$ bunkers were therefore necessary for the fire of a s.F.H.25 or gun at each open emplacement. A commandment bunker or fire direction bunker has not been clearly identified. It could be possible that the battery commandment and fire direction functions were coordinated by the $V f(11)$, also as relay bun- 
ker, on the basis of the data from the one or more telemeters or radar in the hexagonal emplacement on the coverage of the $R 669$ or from another base, as in the case of the Kullack artillery battery at Saint Coulomb (Tomezzoli \& Pottier 2016a). The $M 134 s$ (6), (21) hosting ammunitions were disposed for security reasons on the west side of the battery, relatively far from the gun emplacements. The air protection of the battery was assured by light antiaircraft guns of the Flak $V f(7)$ and (20) and on probably also in the hexagonal emplacement on the coverage of the R669. Emplacements for projectors were not identified. The power supply of the battery remained unknown. It is possible that the battery received electrical power from the public French power network or that electrical power was produced by autonomous electrical generators inside some $V f$ bunker. However, no trace of a possible fuel depot for said generators and vehicles has been identified. The parade ground, wooden barracks hosting battery services like a radio station, further soldiers' lodgments, one or more canteens, one or more kitchens, cinema, douches and latrines were probably located on the central area (b) of the battery. The personnel in service at the battery can be roughly estimated at about 300 - 400 officers and soldiers.

\section{Conclusion}

As have been shown, the Vfs in the German heavy artillery battery of Cleus Foz represented the majority of its bunkers. Because of their easy and rapid construction they provided solutions to the battery necessities of storing materials, lodging personnel and sustaining the combat function of the $R 669$ by providing further combat positions.

\section{References}

Dupont, A., \& Peyle, E. (1994). Le Mur de l'Atlantique sur la Côte d'Emeraude. In Danclau (Ed.), 1st Trimestre, ISBN 2907019201 , 9782907019200.

Chazette, A., Destouches, A., \& Paich, B. (1995). Album Mémorial Atlantikwall, Le Mur de L'Atlantique en France 1940-1944, Heimdal (Ed.), ISBN 2.84048-088-3.

Duquesne, R. (1976). Normandie 44 Le Mur de L'Atlantique, Batteries d'Artillerie Cotière, Heimdal, B. (Ed.)

Patrimoine Region Bretagne (2002). http://patrimoine.region-bretagne.fr/gertrude-diffusion/dossier/batterie-lourde-4-cano ns-de-15-cm-sfh25-av-67/ec4ee521-daec-43f7-affb-0219f0627e96

Rudi, R. (1988). Typologie du Mur de l'Atlantique, Beetsterzwaag, ISBN 9064760453, NUGI 923.

Tomezzoli, G., \& Marzin, Y. (2015). The EroVili and the Atlantic Wall. Advances in Anthropology, 5, 183-204. http://dx.doi.org/10.4236/aa.2015.54018

Tomezzoli, G. T., \& Pottier, L. L. (2016a). Journey through the Defenses of the Festung Saint-Malo (FR)-1. Archaeological Discovery, 4, 125-142.

http://dx.doi.org/10.4236/ad.2016.44010

Tomezzoli, G. T., \& Pottier, L. L. (2016b). Journey through the Defences of the Festung Saint-Malo (FR)-2. Archaeological Discovery, 4, 143-169.

http://dx.doi.org/10.4236/ad.2016.44011 
Tomezzoli, G. T. (2017). The German Radar Surveillancea round the Aber Wrach during the WW II. Archaeological Discovery, 5, 22-41.

http://dx.doi.org/10.4236/ad.2017.51002

Submit or recommend next manuscript to SCIRP and we will provide best service for you:

Accepting pre-submission inquiries through Email, Facebook, LinkedIn, Twitter, etc. A wide selection of journals (inclusive of 9 subjects, more than 200 journals)

Providing 24-hour high-quality service

User-friendly online submission system

Fair and swift peer-review system

Efficient typesetting and proofreading procedure

Display of the result of downloads and visits, as well as the number of cited articles

Maximum dissemination of your research work

Submit your manuscript at: http://papersubmission.scirp.org/

Or contact ad@scirp.org 